\title{
NUOTOLINIO MOKYMO(SI) IŠŠŪKIAI IR GALIMYBĖS MOKANT(IS) UŽSIENIO KALBŲ IR TOBULINANT SKAITMENINE KOMPETENCIJĄ
}

\author{
Ingrida Galkauskienė, Jūratė Helsvig, Aušra Netikšienė, \\ Jūratė Patackaitė, Violeta Žemaitienè
}

Vilniaus kolegijos Užsienio kalbų centras

\begin{abstract}
Anotacija. Straipsnyje apžvelgiami Švietimo, mokslo ir sporto ministerijos parengti dokumentai, reglamentuojantys mokymą(si) nuotoliniu būdu, analizuojami nuotolinio mokymo(si) tobulintini aspektai ir naujos galimybès, remiantis Lietuvos ir užsienio švietimo ekspertu, Vilniaus kolegijos Užsienio kalbu centro dèstytojų ir studentu, kurie mokèsi 2020-2021 m. užsienio kalbu, nuomone. Straipsnio tikslas - pateikti dèstytojų ir studentu požiūrị i užsienio kalbu mokyma(si) nuotoliniu būdu ir, ịvertinus tyrimo rezultatus, švietimo ekspertu rekomendacijas bei išvadas, kaip igyta patirti pritaikyti nuotolinèms užsienio kalbu mokymo(si) priemonèms kurti, praktiniams užsièmimams organizuoti ir užsienio kalbos mokymo(si) nuotoliniu ar mišriu būdu kokybei užtikrinti.

Visgi remiantis tyrimo rezultatais reikia pripažinti, kad užsienio kalbu mokyti(s) nuotoliniu (palyginti nauju) būdu toliau rinktusi tik 20,5 proc. Vilniaus kolegijos dèstytoju ir studentų. Likusieji mieliau užsienio kalbu mokytu(si) tradiciniu büdu, bendraudami tiesiogiai, be „tarpininku“ - naudodamiesi „,MS Teams" platforma ar virtualioje mokymosi aplinkoje „Moodle“. Tačiau užsienio kalbu mokymas(is) nuotoliniu būdu atskleidè ir tam tikru jo privalumu, kurie turèjo ịtakos tiek studentu, tiek dèstytojų mišraus mokymo(si) būdo, t. y. derinant nuotolini ir kontaktini mokyma(si), pasirinkimui. Tai neabejotinas dèstytoju, atsakingai dirbusiu ir geranoriškai žiūrèjusiu i studentus, nuopelnas.
\end{abstract}

Reikšminiai žodžiai: užsienio kalbu mokymas(is), bendrieji gebejimai, nuotolinis mokymas(is), sinchroninis ir asinchroninis nuotolinis mokymas(is), mišrus mokymas, švietimo kokybe.

Problema. 2020 m. pavasarị šalies dèstytojams ir studentams teko paklusti netikètiems pokyčiams ir vos ne per vieną savaitę paskaitas ir pratybas perkelti $\mathfrak{i}$ virtualią erdvę. Nors Vilniaus kolegijos užsienio kalbų dėstytojai mokẻ kalbų nuotoliniu būdu ir prieš karantiną, nes beveik kiekvienas fakultetas teikè nuotolines studiju programas ir studentai noriai jas rinkosi, visiškas perejiimas prie studijų per nuotoli buvo netiketas ir pareikalavo ne tik daug kruopštaus darbo, bet ir susitelkimo, išmonès bei kūrybiškumo. Tačiau mokymo(si) procesas nenutrūko, nes buvo pasirinkta Vilniaus kolegijos dėstytojų ir studentų jau išbandyta ir senokai naudo- 
jama virtuali mokymosi aplinka „Moodle“ (toliau - VMA „Moodle“), o konferencijoms ir susitikimams - „MS Teams“. Visgi priprasti prie bendravimo nuotoliniu būdu, išmokti naudotis įvairiomis „MS Teams“ programos galimybemis, kaip ir patobulinti savo kvalifikacijai informacinių technologijų srityje prireikẻ laiko. Dabar jau svarstoma, kad dali paskaitų bus galima skaityti ir stebėti nuotoliniu būdu, dirbant ir ne karantino metu, o dėstytojai vis kūrybiškiau galès taikyti ịvairias virtualias mokymo(si) aplinkas ir ịrankius bei inovatyvias mokomąsias programas. Tačiau tam, kad protingai, efektyviai ir kokybiškai ir toliau vyktų užsienio kalbų mokymas(is) nuotoliniu būdu, vis dažniau kalbant apie studijas mišriu būdu, straipsnio autorès siekè išsiaiškinti 2020-2021 m. m. Vilniaus kolegijos studentu ir Užsienio kalbų centro (toliau - UKC) dèstytojų požiūrị ị pasirengimą ir perejjimą nuo tiesioginio prie nuotolinio užsienio kalbų mokymo(si) karantino Lietuvoje metu ir užsienio kalbų mokymo(si) Vilniaus kolegijoje nuotoliniu būdu tobulintinus aspektus. Sužinoti kolegijos dèstytojų ir studentų nuomonę šiuo klausimu ir ịsigilinti ị mokslinę literatūrą bei dokumentus šia tema paskatino dar ir tai, kad užsienio kalbų mokymas(is) skiriasi nuo kitų dėstomų dalykų studijų, nes mokant(is) kalbų kaip niekur kitur svarbus tiesioginis bendravimas, grižtamasis ryšys ir kūrybiškumo ugdymas, o mokant(is) nuotoliniu būdu ir neturint tinkamos skaitmeninio raštingumo kompetencijos tai užtikrinti sunku.

Ar tikrai dèstytojai ir studentai, nors ir gana gerai ịvaldę informacines technologijas, pasirengę nuotoliniam užsienio kalbų mokymui(si)? O jeigu taip, kaip optimizuoti nuotolinių studijų procesą, kad jis būtų veiksmingas, mokymas - efektyvus ir kokybiškas, o svarbiausia - kad tiek studentai, tiek dèstytojai pasiektų laukiamus rezultatus? Kokia yra mišraus mokymo patirtis ES šalyse ir ar šis būdas rekomenduotinas Europos Tarybos (toliau - ET) ir Europos Komisijos (toliau - EK) mokslo ekspertų?

Tyrimo objektas - užsienio kalbų mokymas(is) nuotoliniu būdu Vilniaus kolegijoje karantino Lietuvoje metu 2020-2021 m. m.

Tyrimo tikslas - išanalizuoti Europos Komisijos, Lietuvos Respublikos švietimo, mokslo ir sporto ministerijos (toliau - ŠMSM) ir Vilniaus kolegijos (toliau VK) dokumentus, susijusius su užsienio kalbų mokymu(si) nuotoliniu būdu, nustatyti ir įvertinti tobulintinus užsienio kalbų mokymo(si) nuotoliniu būdu aspektus.

Tyrimo uždaviniai: 1) apžvelgti literatūroje ir dokumentuose pateikiamas nuotolinio mokymo(si) sampratas; 2) išsiaiškinti VK studentų ir UKC dèstytojų požiūrị ị užsienio kalbų mokymą(si) nuotoliniu būdu 2020-2021 m. m.; 3) įvertinti VK ir UKC dèstytojų pasirengimą užsienio kalbų mokymui(si) nuotoliniu būdu; 4) pasiūlyti VK UKC išvadas kalbų mokymo(si) kokybei nuotoliniu būdu gerinti.

Tyrimo metodai: dokumentų ir mokslinès literatūros analizė, anketinė apklausa, pusiau struktūruotas interviu.

EK ir LR ŠMSM dokumentų ir mokslinès literatūros nagrinèjama tema analizè padès išsiaiškinti nuotolinio mokymo(si) sampratas ir atskleisti užsienio kalbu mokymo(si) nuotoliniu būdu ypatumus. Pasirinkta MS Office 365 apklausų, vykdy- 
tų rudens ir pavasario semestrą, forma leido apklausti beveik 80 proc. visų 2020 2021 m. m. užsienio kalbas (vokiečių, rusų, prancūzų, ispanų, norvegų ir italų) ir 63 proc. verslo, specialybès ir profesinę anglų kalbą nuotoliniu būdu studijavusių VK studentų, taip pat 93 proc. VK UKC dèstytojų. Ši nuomonè, o taip pat pusiau struktūruoto VK UKC dèstytojų ir partnerių, Lietuvos kalbų pedagogų asociacijos narių interviu reikalingi užsienio kalbų mokymo(si) nuotoliniu būdu tobulintiniems aspektams nustatyti, ịvertinti ir, remiantis EK ir LR ŠMSM rekomendacijomis, išvadoms VK fakultetų administracijai pateikti dẻl užsienio kalbų mokymo(si) nuotoliniu būdu kokybès gerinimo.

\section{Nuotolinio mokymo(si) sampratos EK, Lietuvos ir VK dokumentuose}

ŠMSM (iki 2019 m. ŠMM - Švietimo ir mokslo ministerija) leidinyje, skirtame politikams, savivaldybių švietimo padalinių specialistams ir plačiajai visuomenei, išsamiai ir glaustai pateikiama nuotolinio mokymo(si) samprata ir rūšys (Švietimo problemos analize, 2012). Šiame straipsnyje teigiama, kad nuotolinis mokymasis (angl. distance learning) - tai nuoseklus savarankiškas ar grupinis mokymas(is), kai besimokančiuosius ir mokytoją, dèstytoją skiria atstumas ir (ar) laikas, o bendravimas ir bendradarbiavimas vyksta, mokoji medžiaga pateikiama informacinèmis ir komunikacinèmis technologijomis (Švietimo problemos analizé, 2012). Čia pateikiamos trys nuotolinio mokymo(si) rūšys pagal mokymo(si) laiką: sinchroninis, asinchroninis ir mišrusis. Sinchroninis nuotolinis mokymas(is) mokymas(is) fiksuotu laiku, naudojant vaizdo ar garso konferencijų būdą, t. y. tam tikroje vietoje. Asinchroninis nuotolinis mokymas(is) vyksta bet kur ir bet kuriuo metu, naudojantis informacinėmis ir komunikacinėmis technologijomis ar net paprastu elektroniniu paštu. Mišrusis nuotolinis mokymas(is) turi ir sinchroninio, ir asinchroninio mokymo(si) elementų (Švietimo naujienos, 2021, cit. iš Simonson, Smaldino, Albright, Zvacek, 2008).

Straipsnyje „Nuotolinis mokymas ar mokymo organizavimas nuotoliniu būdu?" (Švietimo naujienos, 2020) pateikiamas dar vienas sąvokos, reguliuojančios ši procesą ŠMSM dokumentuose, apibrěžimas. Mūsų kasdienybëje vadinamasis nuotolinis mokymas įvardijamas kaip „mokymas nuotoliniu ugdymo proceso organizavimo būdu“. Straipsnio „Nuotolinis mokymas ar mokymo organizavimas nuotoliniu būdu" autoriai samprotauja, kad be mokytojo (dèstytojo) nuotolinis mokymas virtualioje erdveje savaime nevyksta. Net jeigu visa medžiaga būtu perkelta ị mokymo(si) platformas, reikètų organizuoti ir valdyti mokymo procesą, todèl mokytojo (dèstytojo) vaidmuo yra nepaprastai svarbus ir reikalingas, o sąvoka „nuotolinis mokymas“ nèra tiksli šiam procesui apibūdinti ir ją rekomenduojama vadinti „mokymu(si) nuotoliniu būdu“. 2020 m. liepos 15 d. internetinèje Europos mokyklos ugdymo platformoje paskelbtame EK dokumente „Mišrusis mokymas mokykliniame ugdyme: gairès 2020-2021 mokslo metu pradžiai“ daugiausia dèmesio skiriama mišriajam mokymui(si) (blended learning), kuris suprantamas kaip 
mokymas(is) derinant nuotolinị ir tiesioginị būdą, ir siūlomi sprendimai, leidžiantys užtikrinti mokinių, tėvų, studentų, mokytojų ir dėstytojų tinkamą pasirengimą tokiam darbui ir jų gerovę. Nė viename iš šių minimų dokumentų nebuvo išskirtinio dèmesio nei užsienio kalbų, nei kitų dalykų mokymui(si) nuotoliniu būdu. Konkrečius sprendimus dèl mokymo(si) formos remdamasi EK rekomendacijomis galejo priimti kiekviena Europos Sajungos šalis atskirai, o Lietuvos aukštosios mokyklos laikèsi mūsų šalies vyriausybès nutarimų. Tad pagal $2019 \mathrm{~m}$. balandžio $3 \mathrm{~d}$. Akademinès tarybos patvirtintą Nr. AT B-4 Nuotolinių studijų Vilniaus kolegijoje organizavimo ir vykdymo tvarkos aprašą, reglamentuojantį nuotolinių studijų vykdymą, dėstytojų ir studentų funkcijas ir atsakomybę, nuotolinès studijos Vilniaus kolegijoje gali būti organizuojamos ir vykdomos nuotoliniu arba mišriuoju būdu. Nuotolinès studijos Vilniaus kolegijoje organizuojamos pasitelkiant informacines komunikacines technologijas, kai dèstytojas ir besimokantieji nèra toje pačioje erdvejje ir (arba) gali komunikuoti skirtingu laiku, o mišriuoju būdu vykdomos studijos organizuojamos, kai, be tradicinių studijų formų, naudojama virtuali mokymosi aplinka ir kitos nuotolinių studijų priemonès. Studijas vykdant mišriuoju būdu, užsièmimai (paskaitos, seminarai, individuali parama besimokantiesiems, diskusijos, užduočių atlikimas, vertinimas) organizuojami tiek auditorijose, tiek virtualioje mokymosi aplinkoje ar sinchroninių / asinchroninių vaizdo konferencijų būdu. Vilniaus kolegijoje galimas ir asinchroninis mokymas(is), kai studentai studijuoja ir gilinasi ị mokomają medžiagą savarankiškai bet kuriuo jiems patogiu metu virtualioje mokymosi aplinkoje VMA „Moodle“ (ATN-1, 2021). Jau daugeli metų Vilniaus kolegijoje teikiamas išskirtinis dèmesys atviriems švietimo ištekliams, tad mokant(is) nuotoliniu būdu skatinama naudotis įvairių rūšių skaitmeninėmis mokymosi priemonèmis.

Visuose šiuose dokumentuose nurodoma sinchroninio ir ypač asinchroninio nuotolinio mokymo(si) nauda asmenims, kurie negali atvykti ị mokymo ịstaigą (pvz., yra užsienyje), dirba ir nori tobulintis, turi mokymo(si) sunkumų (t. y. greitai išsiblaško bei lèčiau suvokia naują informaciją), specialiųų ugdymosi poreikių, daug keliauja, nes siekia muziko, menininko ar sportininko karjeros, gydosi ligonineje ar sanatorijoje, turi psichologinių bendravimo problemų, taip pat yra labai gabūs, gebantys greičiau nei kiti mokytis. Vilniaus kolegijoje ir iki karantino nuotolines studijas rinkosi studentai, kurie sẻkmingai dirbo užsienio įmonèse Lietuvoje, taip pat kitose Europos šalyse, savarankiškai mokèsi ir konsultuodavosi, tie, kurie negalėdavo dèl sveikatos ar kitu priežasčių dalyvauti paskaitose, seminaruose ar juos praleisdavo, bei nutraukę studijas ir vél panorę jas tęsti. Tačiau kai visas studijų procesas 2020-2021 m. m. buvo organizuojamas nuotoliniu būdu, straipsnio autorès domëjosi, kokius teigiamus ir neigiamus tokių studijų aspektus įžvelgia Vilniaus kolegijos studentai ir dèstytojai.

Remiantis apklausų rezultatais ( 1 pav.), tiek dèstytojai, tiek studentai įžvelgia šiuos nuotolinio darbo privalumus: net 70 proc. apklaustujų tai mato kaip puikią galimybę derinti darbą ir asmenini gyvenimą, o 60 proc. respondentų - kaip gali- 
mybę mažinti kelionès išlaidas. Tiek pat jų nurodè nuotolinị darbą ir kaip galimybę savarankiškai paskirstyti darbo dienos laiką. 30 proc. respondentų mokydamiesi nuotoliniu būdu patiria mažiau streso ir labiau susitelkia ị darbą, todèl jis produktyvesnis. Galimybės pasirinkti patogią aprangą ar darbą derinti su artimujjų priežiūra apklaustiesiems nebuvo aktualios.

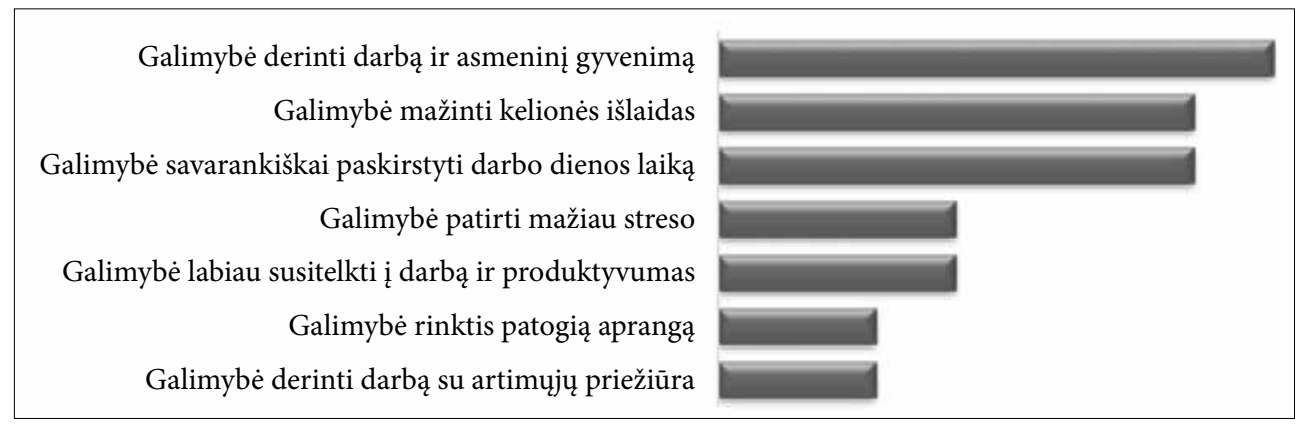

1 pav. Nuotolinio darbo privalumai, studentų ir dèstytojų nuomone

Taigi, sinchroninio ir asinchroninio nuotolinio mokymo(si) metu tiek studentams, tiek destytojams lengviau suderinti darbo, šeimos reikalus ir studijas. Ypač tai akcentavo paskutinių kursų studentai, kurie mokèsi antrosios užsienio kalbos ir buvo susiradę nuolatines darbo vietas, taip pat užsienio studentai, atvykę studijuoti pagal ERASMUS+ programą. Kolegijos administracijos atstovai, apklausti interviu būdu, nuotolinị mokymą(si) nurodè kaip vieną priemonių taupyti lèšas arba efektyviau jas naudoti, taip pat kaip galimybę studijuoti asmenims su negalia. Lietuvos kalbų pedagogų asociacijos nariai interviu teigè, kad nuotolinis mokymas(is) yra veiksmingas būdas skatinti asmenis tęsti mokymąsi ir mokytis visą gyvenimą, kad tai - galimybe igyti išsilavinimą, kelti kvalifikaciją visiems, o ypač turintiems specialiujjų ugdymosi poreikių, gyvenantiems kaime, vyresnio amžiaus asmenims ir pan. UKC atstovams - tai galimybè, taupant laiką ir pinigus, organizuoti mokymus ir kvalifikacijos kèlimo ar tobulinimo kursus darbo vietoje ir efektyviai naudoti lěšas.

\section{Užsienio kalbų mokymas(is) nuotoliniu būdu}

COVID-19 pandemija kasdienį mokymąsi kabinetuose pakeitè retai ugdymo praktikoje ne tik Lietuvoje, bet ir kitose Europos Sajungos šalyse taikytas nuotolinis mokymo(si) būdas. Bet Europos Tarybos (ET) bendrujų kompetencijų rekomendacijos ugdymo ịstaigoms išliko. Nors ES šalių aukštosiose mokyklose mokoma verslo, specialybès, arba profesinès, užsienio kalbos, kalbų mokymas (išskyrus kalbų studijas) dažnai priskiriamas bendrujjų kompetencijų sričiai. Tačiau tai nèra blogai, nes tiek mokslininkai, tiek politikai supranta, kad svarbiausia - igyti pagrindus. O aukštujų mokyklų dėstytojai, turintys užtikrinti tęstinumą, vieningai atsakytų - ne 
bet kokius, o tvirtus pagrindus, ir nesvarbu, matematikos ar biologijos, užsienio kalbų ar kitų dalykų. Todèl ET atnaujinti orientaciniai metmenys teikia vilčių, kad tiek gimtosios, tiek užsienio kalbų mokymui(si) bus skiriamas tinkamas demesys, nes „sparčiai kintančiame ir glaudžiai tarpusavyje susijusiame pasaulyje kiekvienam žmogui reikès iggyti ịvairių ịgūdžių ir kompetencijų ir juos nuolat tobulinti visą gyvenimą. Šiuose orientaciniuose metmenyse apibrèžtomis bendrosiomis kompetencijomis siekiama sukurti pagrindą, padèsiantị siekti lygesnès ir demokratiškesnès visuomenès. Jos atitinka ịtraukaus ir tvaraus augimo, socialinès sanglaudos ir tolesnio demokratinès kultūros plètojimo poreikị"“ - teigiama Europos Tarybos $2018 \mathrm{~m}$. gegužès $22 \mathrm{~d}$. rekomendacijose dèl bendrujų mokymosi visą gyvenimą gebejjimų (Europos Tarybos rekomendacija, 2018, p. C 189/7).

Orientaciniuose metmenyse yra nustatytos aštuonios bendrosios kompetencijos:

- raštingumo kompetencija;

- daugiakalbystès kompetencija;

- matematiné kompetencija, gamtos mokslų, technologijų ir inžinerijos kompetencija;

- skaitmeninè kompetencija;

- asmeniné, socialinè ir mokymosi mokytis kompetencija;

- pilietiškumo kompetencija;

- verslumo kompetencija;

- kultūrinio sąmoningumo ir raiškos kompetencija (Europos Tarybos rekomendacija, 2018).

Mokant(is) užsienio kalbų nuotoliniu būdu svarbios visos kompetencijos, tačiau šiuo metu ypač aktualios trys: raštingumo, daugiakalbystès ir skaitmeninė. Todèl pasigilinkime išsamiau, kokie reikalavimai keliami ES šalių mokymo institucijoms, kurios vadovaujasi šiomis trimis kompetencijomis. „Priklausomai nuo aplinkybių raštingumo kompetenciją galima ugdyti gimtaja kalba, mokymo kalba ir (arba) šalies ar regiono oficialiaja kalba. Asmuo turètų gebèti žodžiu ir raštu bendrauti įvairiose situacijose, atskirti ir naudoti skirtingų tipų šaltinius, ieškoti informacijos, ją rinkti ir apdoroti, naudotis pagalbinėmis priemonėmis, žodžiais ir raštu formuluoti argumentus ir ịtikinamai juos dèstyti, kritiškai mąstyti ir vertinti informaciją“ (Europos Tarybos rekomendacija, 2018, p. C 189/8).

Daugiakalbystės kompetencija - gebejimas bendraujant tinkamai ir veiksmingai vartoti iqvairias kalbas - svarbi besimokantiems ir mokantiems antrosios arba trečiosios užsienio kalbų, kurių Vilniaus kolegijoje mokoma(si). Čia keliami kiti reikalavimai, nes asmuo turi išmanyti tam tikros užsienio kalbos gramatiką ir žodyną, suprasti žodžiu perduodamą žinią, pradèti, palaikyti ir užbaigti pokalbị, skaityti, suprasti ir rengti tekstus. To mokoma atsižvelgiant ị skirtingą kalbų mokejjimo lygị, pagal asmens poreikius, kartu siekiama, kad jis išmanytų kultūrinius aspektus, pastebėtų kalbų variantiškumą, mokètų tinkamai naudotis mokymo priemonemis ir visą gyvenimą mokytis kalbų formaliuoju, neformaliuoju ar savaiminiu 
mokymosi būdais (Boeckmann, Aalto, Abel, Atanasoska ir Terrz Lamb, 2011).

Vilniaus kolegijos Užsienio kalbų centro dèstytojai, laikydamiesi rekomendacijų, pirmaja užsienio kalba - anglų, kurios dabar mokosi 99,7 proc. visų kolegijos studentų, siekia ugdyti užsienio kalbos komunikacinius gebėjimus, apimančius keturias pagrindines kalbinès veiklos rūšis: kalbẻjimą, rašymą, klausymo ir skaitymo supratimą. Verslo, specialybès, arba profesinès, užsienio kalbos moduliu siekiama, kad studentai gebètų bendrauti užsienio kalba darbo aplinkoje, susirasti, atsirinkti, analizuoti ir apdoroti informaciją, ją suprasti ir kritiškai vertinti, taip pat formuluoti užsienio kalba mintis žodžiu ir raštu, atlikti kitas programoje numatytas užduotis.

Mokant kitų užsienio kalbų (kurios sudaro modulị) ugdomi bendrieji komunikaciniai gebèjimai, apimantys keturias pagrindines kalbinès veiklos rūšis: kalbèjimą ir rašymą, klausymo ir skaitymo supratimą, taip pat formuojami ịgūdžiai pagal asmeninius studento interesus ir poreikius, suteikiama žinių apie mokomos kalbos šalies kultūrą. Siekiama, kad modulio studentai iggtų bendrinès užsienio kalbos pagrindus, gebètų susirasti, suprasti ir atsirinkti informaciją, atlikti programoje numatytas užduotis žodžiu ir raštu. Šie reikalavimai antrosios ir trečiosios užsienio kalbos studijoms parengti vadovaujantis Šiuolaikinių Europos kalbų centro daugiakalbystės rekomendacijomis (Hufeisen ir Neuner, 2005).

Taigi, ES Tarybos ir Šiuolaikinių Europos kalbų centro rekomendacijų rengejjai supranta, kad kultūrų tarpusavio supratimas ir bendradarbiavimas tampa vis svarbesni šiuolaikinėms visuomenėms, o UKC dėstytojai suvokia jiems keliamus uždavinius - padèti studentams kelti kalbinių kompetencijų lygị, išmokti kitu jų darbui ir gyvenimui svarbių užsienio kalbų, kurios neabejotinai ateityje pravers tarpvalstybinès komunikacijos ir mobilumo srityse, darbo aplinkoje, siekiant karjeros ar kuriant ir realizuojant save. Šie siekiniai, be abejo, išlieka aktualūs, nesvarbu, ar mokoma(si) kalbų nuotoliniu, ar ịprastu kontaktiniu būdu.

Tik kaip niekad svarbus pasirengimas studijoms, t. y. bendrojo lavinimo mokyklose igytos žinios ir praktiniai užsienio kalbų (anglų kalbos) gebejjimai, kad minèti tikslai būtų igyvendinti. Tuo tikslu Užsienio kalbų centro dėstytojai buvo paprašyti nurodyti, kokie anglų kalbos igūdžiai stiprejja ir kokie silpsta, kokių igūdžių trūko pirmo kurso studentams, tik ịstojusiems ị Viniaus kolegiją. $2020 \mathrm{~m}$. i ją įstojusiems studentams labiausiai trūko rašymo ịgūdžių, mažiau - skaitymo supratimo. Paskutiniais metais UKC dèstytojai pastebi ir toliau silpstančius rašymo, tačiau stiprèjančius kalbèjimo, skaitymo ir klausymo supratimo igūdžius (2, 3, 4 pav.). 


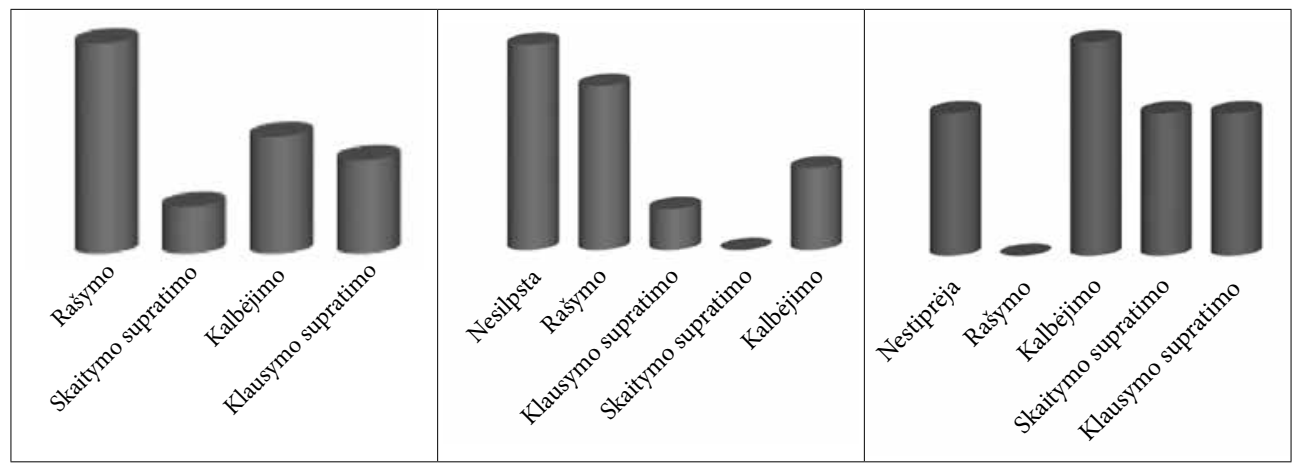

2 pav. Kokių anglų k. igūdžių trūko?
3 pav. Kokie anglų $\mathrm{k}$. igūdžiai silpsta?
4 pav. Kokie anglų k. igūdžiai stiprèja?

Kadangi, kaip jau buvo minèta anksčiau, užsienio kalbų, ypač antrosios ir trečiosios, mokymui(si) labai svarbūs bendrieji gebejjimai, UKC dèstytojai ịvertino i̊stojusiujų ị Vilniaus kolegiją bendrųjų gebejjimų stoką.

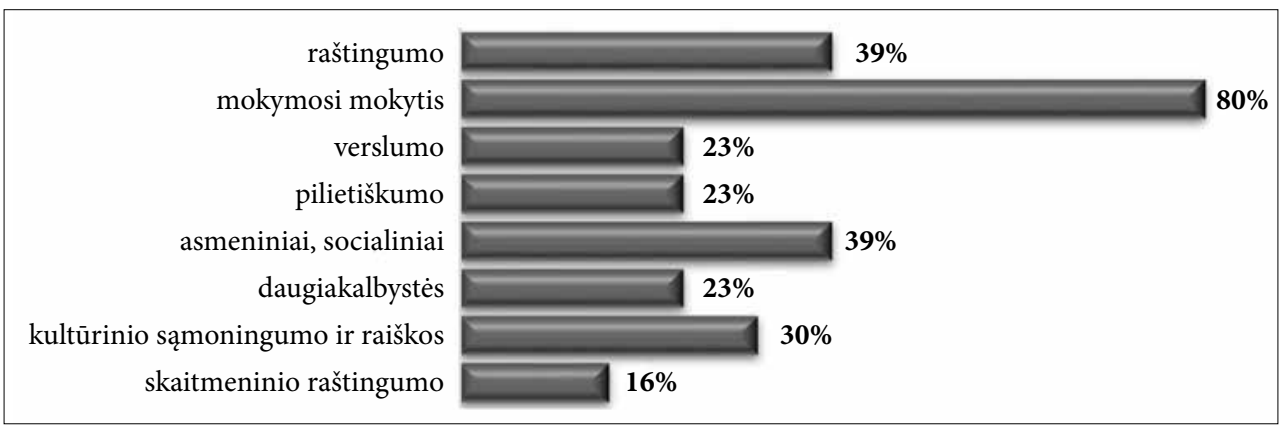

5 pav. UKC dèstytojų vertinimas, kokių bendrujų gebejjimų trūksta ịstojusiems ị Vilniaus kolegiją

Mokymosi mokytis gebėjimas (5 pav.) jau daugelị metų yra didelė problema, kuri trukdo ne tik mokytis užsienio kalbų, bet ir apskritai studijuoti pagal pasirinktą studijų programą. Raštingumo bei asmeninių ir socialinių gebèjimų trūkumas turi įtakos studentų pasiekimams ir įvertinimams. Skaitmeninio raštingumo gebejjimas džiugina ir teikia vilčių, kad nuotolinis užsienio kalbų mokymas(is) gali būti efektyvus ir kūrybingas.

\section{Stipriosios pusės ir tobulintini aspektai mokant(is) užsienio kalbų nuotoliniu būdu}

Dabartinis informacinių ir komunikacinių technologijų lygis ir ịvairovė suteikia daug ir įvairių nuotolinio mokymo(si) galimybių: nuo susirašinėjimo iki virtualiųjų klasių. Šiuo metu dažniausiai nuotolinis mokymas(is) vyksta įvairiomis 
interneto priemonėmis: naudojantis virtualiaja mokymosi aplinka, vaizdo konferencijomis, atviraisiais švietimo ištekliais ir kt. Iki karantino Vilniaus kolegijos dèstytojai ir studentai naudojo virtualią mokymo(si) aplinką „Moodle“, kūrè e. dalykus (modulius) nuotolinèms studijoms, vyko intensyvūs mokymai ir konsultacijos, kaip ịdèti parengtą medžiagą, kurti testus, importuoti ir paruošti klausimus, kaip stebèti studentų dalyvavimą virtualioje paskaitoje, organizuoti egzaminus ir vertinti atliktas užduotis. Tačiau jau pirmoji nuotolinio mokymo(si) savaite karantino metu parodè, kad vienos VMA „Moodle“ nepakanka, ir anksčiau Vilniaus kolegijoje mažai mokymui(si) naudota „MS Teams“ tapo antraja ir aktyviai taikoma skaitmenine platforma. Taip galima teigti išanalizavus studentų ir dėstytojų apklausų rezultatus. Kaip matyti iš 6 pav. ir 7 pav., užsienio kalbų mokymąsi karantino metu VMA „Moodle“ aplinkoje 74 proc. apklaustų studentų ir 79 proc. „MS Teams“ aplinkoje studijavusių studentų ịvertino teigiamai.

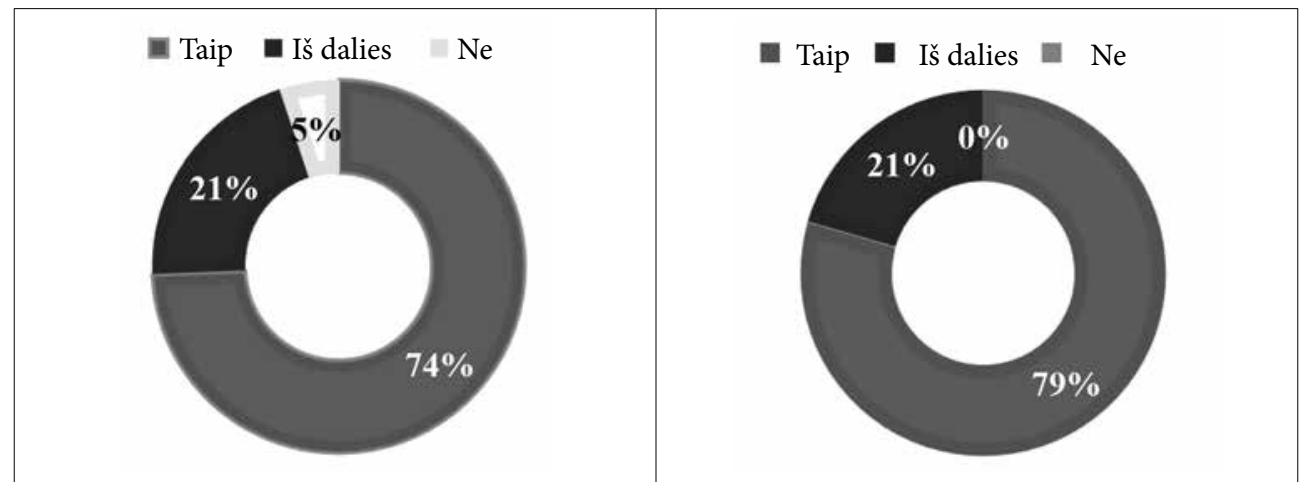

6 pav. Pasitenkinimas užsienio kalbos mokymusi VMA „Moodle“

7 pav. Pasitenkinimas užsienio kalbos mokymusi „MS Teams“ aplinkoje

UKC dèstytojų nuomone, „MS Teams“ aplinka labiau nei VMA „Moodle“ tinka kalbų mokymui. Taip teigia net 77 proc. apklaustųų (8 pav.). O VMA „Moodle“ tinkamumą kalbų mokymui patvirtino tik 23 proc. (9 pav.) kalbininkų.

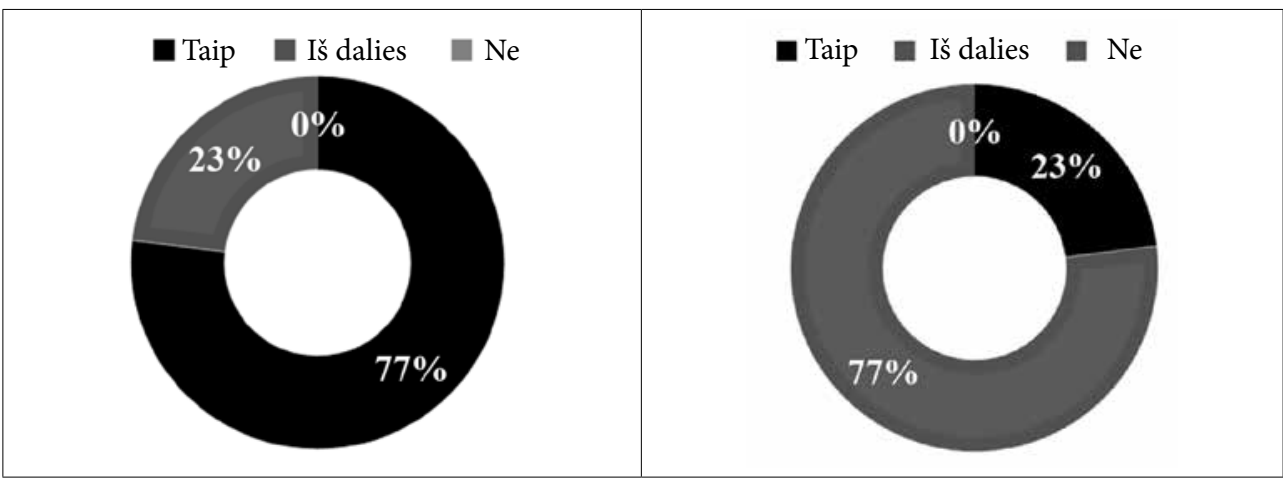

8 pav. UKC dèstytojų nuomonè apie „MS Teams“
9 pav. UKC dèstytojų nuomonè apie VMA „Moodle“ 
Kokios priežastys lèmè, kad užsienio kalbų mokymą „MS Teams“ aplinkoje Vilniaus kolegijos kalbininkai vertina palankiau nei darbą VMA „Moodle“, nors šioje aplinkoje tiek studentai, tiek dèstytojai dirba ilgiau. Pirmoji priežastis - „MS Teams" platformos įrankių, tinkamų ir paskaitoms vesti, ir konsultacijoms organizuoti, ịvairovè. Net 88 proc. (10 pav.) apklausoje dalyvavusių dèstytojų susirašinejjimui, dokumentų padalijimui, skaidrių demonstravimui naudoja „MS Teams“ aplinką. 46 proc. jų čia kuria užduotis, testus, 55 proc. dirba su studentais virtualiuose kambariuose, o 40 proc. - tai savarankiškų namų darbų atsiskaitymo platforma. Mažiau naudojamas įrašų kūrimo įrankis, tačiau, ji patobulinus, jo pritaikomumas padidejjo. O konferencijos ir laiko planavimas šioje platformoje tapo jau kiekvieno dèstytojo kasdienybe.

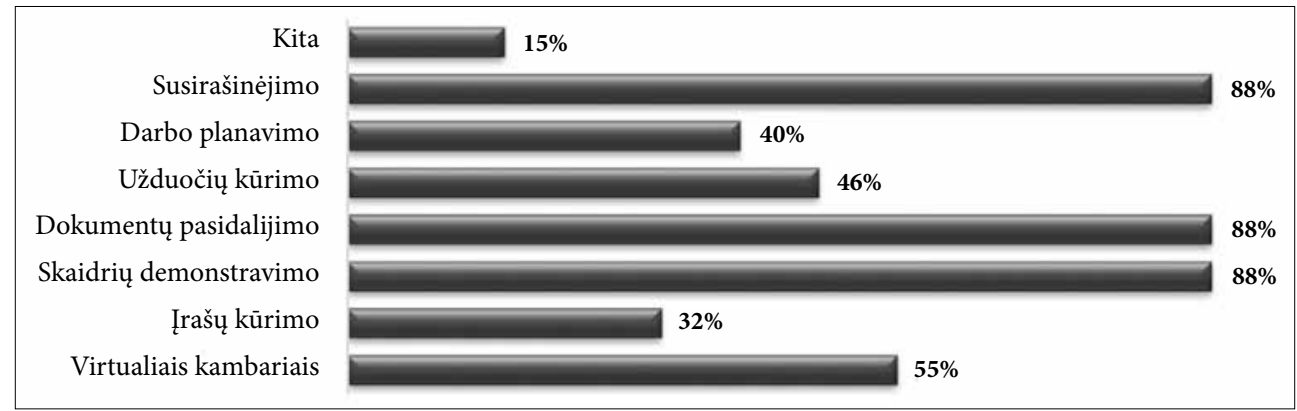

10 pav. „MS Teams“ platformos ịrankių naudojimas paskaitoms vesti ir konsultacijoms organizuoti

Be to, UKC dèstytojai daug kūrybiškiau nei $2020 \mathrm{~m}$. pavasarị naudojo vaizdo ir garso medžiagą iš „YouTube“, „TikTok“, taip pat „Kahoot“, „Quizlet“, „Quizizz“, „Google Forms“, „Google Docs“, „Mentimeter“, „LearningApps“ ir kt. mokymo(si) platformas ir interneto įrankius paskaitoms, apklausoms, viktorinoms, diskusijoms, medžiagos kūrimui ar įtvirtinimui. Tai gelbèjo siekiant sutelkti studentų dėmesị, organizuojant savarankišką darbą, norint greičiau sulaukti grižztamojo ryšio ar sužinoti studentų pažangą, taip pat įdomiau pateikti mokomąją medžiagą.

Vilniaus kolegijos studentai, kurie šiais mokslo metais mokèsi užsienio kalbų: anglų - kaip pirmosios - ir kitų (vokiečių, prancūzų, italų, ispanų, norvegų, švedų, rusų) - kaip pasirenkamųjų dalykų (modulių), gana gerai ịvertino jiems parengtas pratybų, paskaitų ir savarankiško darbo namuose užduotis. 80 proc. (11 pav.) apklaustujų anglų kalba parengtos ir VMA „Moodle“ bei „MS Teams“ pateiktos užduotys buvo suprantamos ir tik 7 proc. studentų užduotys „MS Teams“ ir 8 proc. VMA „Moodle“ nesuprantamos. Tačiau 35 proc. ir 44 proc. apklaustų studentų teigè, kad šioms užduotims, atitinkamai pateiktoms „MS Teams“ ir VMA „Moodle“ aplinkose, atlikti reikejo dėstytojo(s) konsultacijų. 


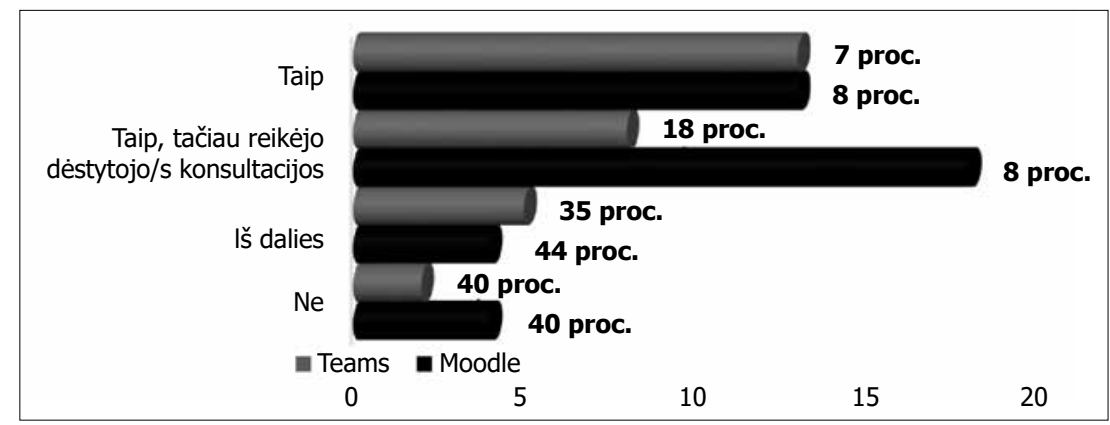

11 pav. Ar anglų kalbos užduotys VMA „Moodle“, „MS Teams“ buvo Jums suprantamos?

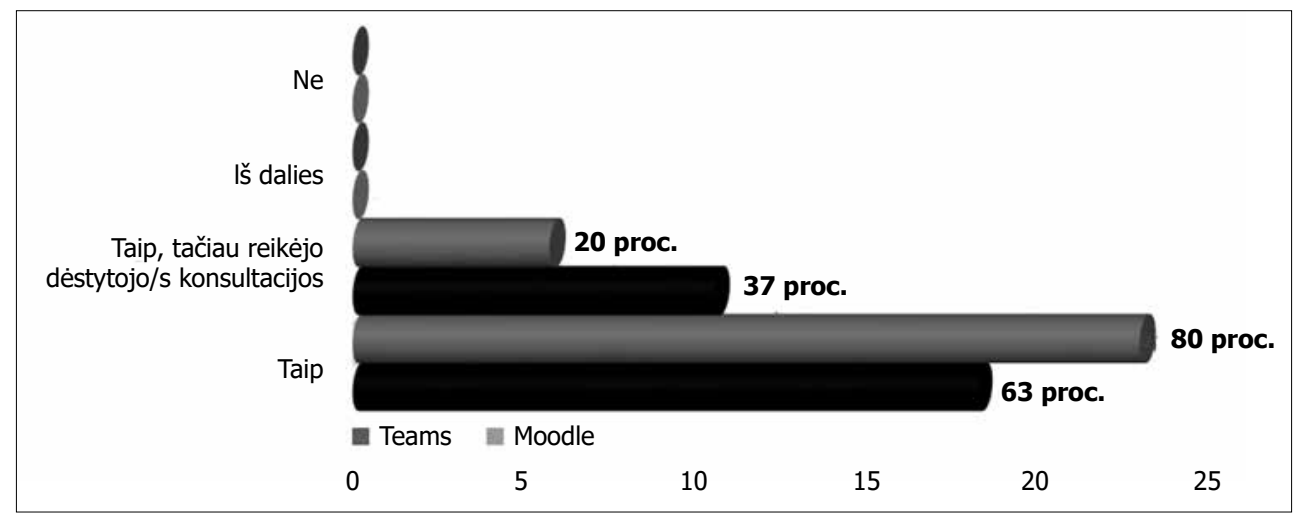

12 pav. Ar kitų užsienio kalbų užduotys VMA „Moodle“, „MS Teams“ buvo Jums suprantamos?

Dar geresni rezultatai buvo gauti, apklausus studentus, kurie mokèsi antrosios arba trečiosios užsienio kalbos: vokiečių, prancūzų, rusų, italų, ispanų, norvegų. Tokiems rezultatams ịtakos turèjo tai, kad dauguma užduočių buvo pradinio kalbos lygio - $\mathrm{A}_{1}$ (išskyrus verslo rusų kalbos $-\mathrm{B}_{1} / \mathrm{B}_{2}$ ). Tačiau čia dèstytojai susidūrè su kitais sunkumais: kaip surasti ar parengti pradinio lygmens, bet studentams (ne moksleiviams) tinkamas užduotis, nes dauguma jau parengtu yra skirtos mažamečiams arba moksleiviams? Visgi, kaip matyti 12 pav., šių kalbų dèstytojams pavyko igyvendinti norimą tikslą, kadangi 80 proc. studentų „MS Teams“ ir 63 proc. VMA „Moodle“ parengtos užduotys buvo suprantamos ir nè vienam nebuvo nesuprantamų užduočių. Tik, kaip matyti 11, 12 ir 13 pav., konsultacijų mokant(is) užsienio kalbų reikejjo daug daugiau. Taip teigia 85 proc. UKC dèstytojų, 39 proc. jų nurodo išaugusị konsultacijų poreiki iš karto po paskaitų ir net 46 proc. - atliekant ịvairias užduotis. 


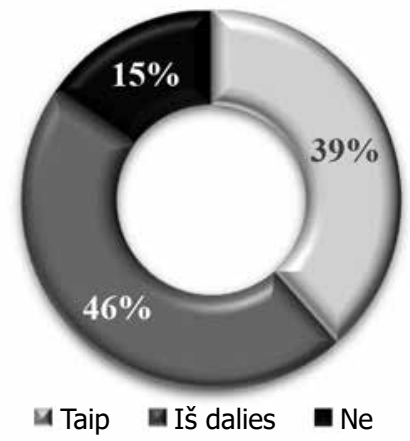

13 pav. Konsultacijų poreikis. Dėstytojų nuomonè

Užsienio kalbų centro dèstytojų taikomi studijų ir vertinimo metodai, parengtos užduotys bei nuolatinès konsultacijos padejo išvengti dèmesio stokos ir studentu užsienio kalbų mokymo(si) spragų. Kaip teigia 75 proc. (14 pav.) apklaustų studentų, nuotoliniu būdu ịgytas anglų kalbos žinias jie ịsisavino puikiai (5 proc.), labai gerai (31 proc.) ir gerai (39 proc.). Kitų užsienio kalbų rezultatais (15 pav.) patenkinti dar daugiau studentų - 93 proc. apklaustuju ( 37 proc. vertino „puikiai“, 43 proc. „labai gerai“" ir 13 proc. - „gerai“).
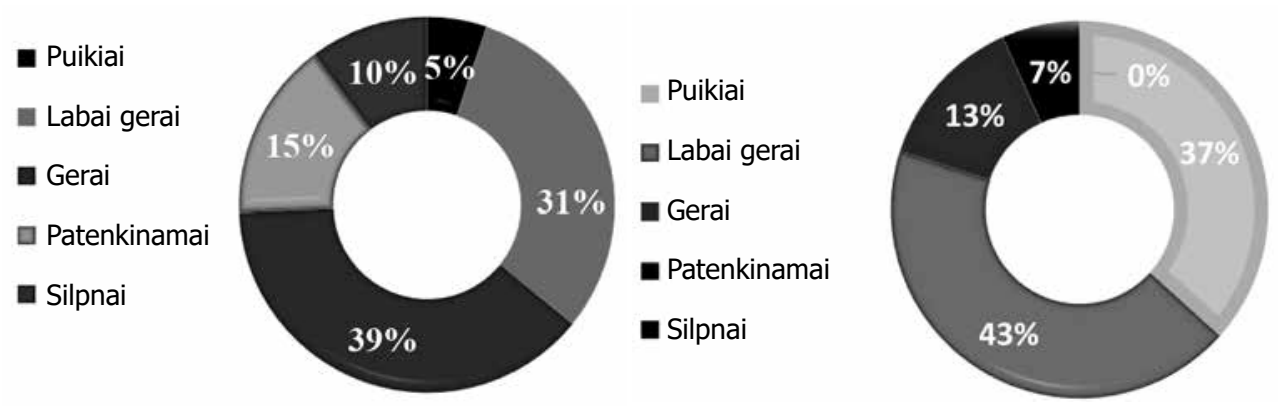

14 pav. Anglų kalbos žinių ịsisavinimas

15 pav. Kitų užsienio kalbų žinių įsisavinimas

Tačiau apklausti studentai nurodè, kad ne viskas jiems taip gerai pavykdavo. Kaip didžiausią trukdị, mokantis užsienio kalbų (16 pav.), jie nurodė asmenines priežastis: neturejo kompiuterio arba jis buvo taisomas, reikejo kompiuterị dalytis su kitais šeimos nariais arba užtruko, kol ji ịsigijo, trūko vaizdo kamerų, ausinių ar pan., kad galètų atsiskaityti arba aktyviai dalyvauti paskaitose, taip pat trukde ligos ar kiti šeimos nariai gyvenamojoje vietoje. Nemažai studentų nurodè ir interneto ryšio sutrikimus paskaitų metu. Kadangi kitų užsienio kalbų mokosi antro arba trečio kurso studentai, rudens semestrą jas pasirinkę, o dalis apklaustujų buvo ištęstinių studijų ir (arba) dirbantys studentai, 29 proc. jų nurodè, kad darbas jiems trukdė aktyviai dalyvauti paskaitose ir mokytis. Tačiau ankstyvas paskaitų laikas (rytas), kaip niekad, mažiausiai turèjo įtakos užsienio kalbų mokymuisi. Panašias 
nuotolinio mokymo(si) silpnąsias puses nurodè ir kitų Lietuvos mokymo institucijų edukologai $2020 \mathrm{~m}$. balandžio-birželio mèn. Vilniaus švietimo agentūros organizuotose konferencijose (Kazragyte, Gudaite, sudaryt., 2020).

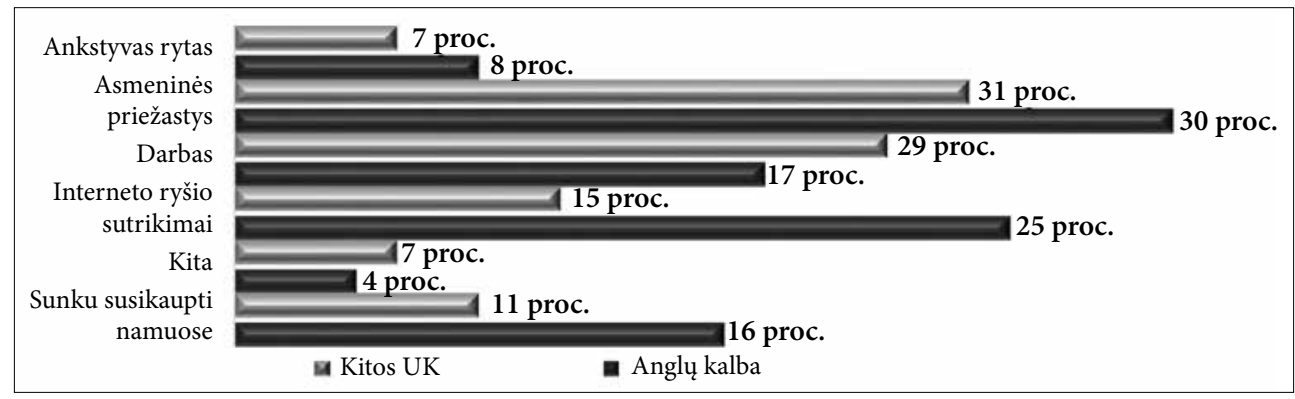

16 pav. Kas trukdè studentams mokytis užsienio kalbų nuotoliniu būdu

UKC dėstytojai pastebejjo, o ir patys studentai teigè, kad nuotolines paskaitas lankè geriau nei kontaktines prieš karantiną, bet nuotolinių paskaitų metu jie buvo ne tokie aktyvūs ir labiau išsiblaškę. Todèl tikras iššūkis buvo dèstytojams prakalbinti juos, dažnai „pasislèpusius“, sudominti užduotimis ir atitraukti nuo pašalinių darbų. Nors užsienio kalbų dėstytojų darbo krūvis visada buvo didelis, nuotolinio mokymo metu jis dar labiau padidejo, ir tai pastebejo 70 proc. kalbininkų (17 pav.). Jie taip pat pasigedo tiesioginio kontakto su studentais ir kolegomis, o tai tikrai suprantama dirbant nuotoliniu būdu.

Nuotolinis darbas pareikalavo ir informacinių bei komunikacinių technologijų išmanymo, kurių 30 proc. apklaustų dèstytojų pritrūko, kad galètų pasinaudoti visomis IT galimybėmis mokydami užsienio kalbų. Tačiau profesiniam tobulèjimui ir skaitmeninei kompetencijai tobulinti UKC dèstytojai turëjo visas galimybes, kadangi Vilniaus kolegijoje buvo organizuojami seminarai, mokymai, parengta medžiaga savarankiškam studijavimui.

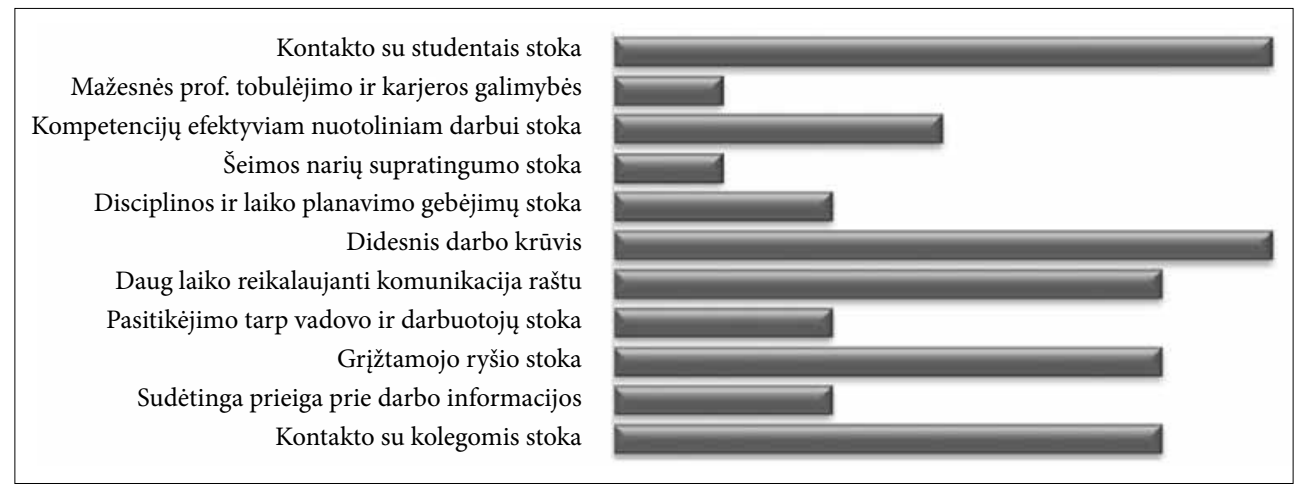

17 pav. Aktualiausi nuotolinio darbo iššūkiai dėstytojams 
İvertinus teigiamus ir neigiamus užsienio kalbų mokymo(si) nuotoliniu būdu aspektus, buvo pasidomèta, ar Vilniaus kolegijos studentai ir UKC dėstytojai keistų nuotolinio mokymo(si) paskaitas ị ,gyvo“ bendravimo. Ši klausimą iškelti paskatino tai, kad situacija tiek šalyje, tiek pasaulyje, nors ir valdoma, kinta ir būtų nedovanotina nepasiruošus vèl atsidurti tokioje padètyje. Kita priežastis - poreikis išgirsti dèstytojų, studentų nuomonę ir, pasinaudojus šia informacija, sukaupta patirtimi, patobulinti užsienio kalbų mokymo turini, studijų ir vertinimo metodus ir jų organizavimo ne tik nuotoliniu būdu procesą. Iš apklausų rezultatų, pateiktų 18 ir 19 pav., paaiškejjo, kad tik 14 proc. UKC dèstytojų ir 29 proc. studentų nuotolini būdą mokyti(is) užsienio kalbų laiko tinkamu.

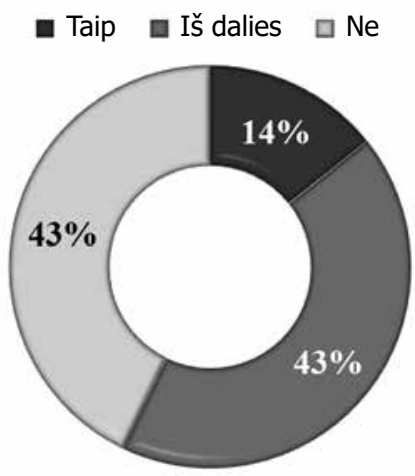

18 pav. Ar tinka nuotolinis būdas užsienio kalbų mokyti?

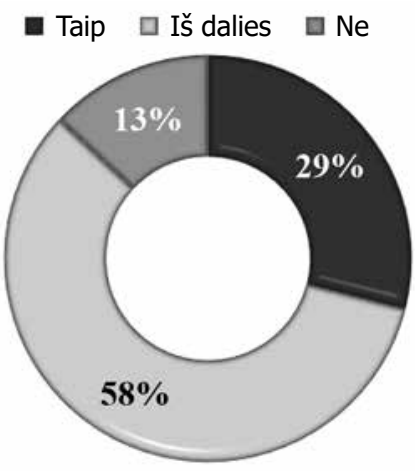

19 pav. Ar tinka nuotolinis būdas užsienio kalbų mokytis?

Dalis Vilniaus kolegijos studentų norètų keisti nuotolinio mokymo(si) užsienio kalbų paskaitas $i \mathfrak{t}$ „gyvo“ bendravimo. Tam nepritartų 13 proc. studentų ir net 43 proc. kalbų dèstytojų, jau anksčiau išsakiusių savo nuomonę dèl „gyvo akių“ kontakto su studentais ir kolegomis trūkumo. Tačiau dauguma studentų (58 proc.) ir gana nemažai dèstytojų (43 proc.), pasirinkę teiginị „iš dalies“, pritartų mišriam studijų būdui, t. y. galimybei derinti nuotolinį ir kontaktinį mokymą(si).

\section{Išvados}

Mokymas(is) nuotoliniu būdu - patogus būdas pateikti informaciją ir mokymo(si) medžiagą. VMA ,Moodle“ - žinoma ir pripažįstama viena pažangiausių nuotolinio mokymo(si) aplinkų, nes lanksti ir leidžia pasirinkti tiek dėstytojui, tiek studentui tinkamiausią mokymo(si) būdą, suteikia galimybę mokyti(s) patogiausiu metu, norimoje vietoje - kaip vieną iš teigiamų mokymo(si) užsienio kalbų aspektų nurodo Vilniaus kolegijos dèstytojai. Tačiau jie susiduria su ịvairiais sunkumais. Vienas jų - didejjanti virtualių mokymo(si) įrankių, platformų įvairové ir efektyvaus jų taikymo įgūdžių stoka. Tai skatina iš naujo įvertinti savo kompetencijas, nes nuotolinis ir mišrusis mokymas reikalauja mokymo(si), skaitmeninès, 
lyderystès, tarpkultūrinès ir tyrimų kompetencijų (Lietuvos Respublikos švietimo, mokslo ir sporto ministro įsakymas Nr. V-936, 2020). Kitas trukdis - nepakankamai spartus švietimo ir mokslo sektoriaus materialinis techninis aprūpinimas. Tai visada kèlè daug diskusijų ir jo vystymąsi galima būtų palyginti su modeliais, kuriuos apibūdina Melnikovas (2007). Dešimtmečius buvo dirbama korespondentinio modelio principu, t. y. su spausdintine medžiaga, toliau buvo diegiamas multimedijos modelis ir naudojamos garso ir vaizdo kasetès, kompaktiniai diskai ir t. t. Trečiojo - „telemokymosi“ modelio etapas, taikant garso ir vaizdo konferencijas, televizijos ir radijo transliacijas, truko gana trumpai, nes pažangūs edukologai pradèjo aktyviai domètis lankstaus mokymosi modeliu, daugelis mokymo institucijų įsigijo interaktyviujų lentų, o internetine prieiga leido naudotis informaciniais ištekliais. Ir tik pažangiausiems edukologams pradėjus naudoti interaktyvią daugialypę terpę, taikyti išmanų ir lankstų mokymo(si) modelį, COVID-19 pandemija privertė visus be išimties dèstytojus ir studentus pasekti jų pèdomis. Todèl šis staigus perejimas, neskiriant ir neturint laiko pasirengimo etapui, turi ir trūkumų, ir privalumų. Aukštụjų mokyklų pedagogams pasiseké, kad jie dirba su studentais, kurių kompiuterinio raštingumo ịūdžiai yra gana geri, nors konsultacijų, mokant užsienio kalbų nuotoliu būdu, prireikè daugiau nei paprastai, taip pat ir sumanumo organizuojant praktinius užsièmimus bei papildomo darbo, rengiant užduotis, tačiau kalbų mokymo kokybei tokios didelės žalos, kaip profesinėms praktikoms ar praktiniams mokymams, nuotolinis mokymas neturèjo. Teigiamas aspektas, organizuojant mokymą(si) Vilniaus kolegijoje nuotoliniu būdu, buvo tas, kad dèstytojai jau iki pandemijos turëjo darbo su VMA „Moodle“ patirties, nors ir ne taip intensyviai, tačiau naudojo „MS Teams“ platformą, be to, buvo vykdomos ir nuotolinès studijos. Čia svarbu paminèti, kad kolegijai pasirinkus šias abi mokymo aplinkas, padidejjo dėstytojų ir studentų lankstumas, ir tai skatino jų kūrybiškumą. Dėstytojai galèjo patys rinktis nuotolinio mokymo formas: sinchronini ar asinchronini, o rudens semestrą iki karantino ir mišrujjị būdą. Tačiau mokymo proceso perkèlimas ị virtualią erdvę pareikalavo daug nenormuoto ir neplanuoto darbo, fizinès ištvermès, susitelkimo, ir tai neabejotinai ateityje turès įtakos ne tik pedagogų, bet ir studentų fizinei ir emocinei sveikatai.

Visgi tenka pripažinti, kaip tyrimo rezultatai rodo, kad nuotolinị mokymą, nors tai ir palyginti naujas mokymo būdas, teigiamai vertina ir studentai, ir dèstytojai. Tikètina, kad taip yra dèl informacinių technologijų pažangos. Tačiau mokymas neturètų būti orientuotas tik ị IT raštingumą (Targamadzè, Girdzijauskienė, Šimelionienè, Pečiuliauskienè ir Nauckūnaitè, 2015), nes jaunimui reikia plètoti ir kitus gabumus. Autoriai teigia, kad skaitmeninis raštingumas remiasi pamatiniu raštingumu, kuris apima tradicinius raštingumo gebèjimus. „Taigi pamatinio raštingumo svarba internetinio raštingumo laikais didejja, nes skaitymo ir rašymo gebejjimai yra esminiai, norint kaip reikiant naudotis internetu ir IKT, tik skaitymas, rašymas ir komunikavimas igauna naujas formas, nes tekstas derinamas su naujomis žiniasklaidos priemonèmis ir susiejamas per sudetingus informacijos tinklus. Tam, kad 
būtų veiksmingai jais naudojamasi, ir reikia naujo raštingumo ịḡdžių“ (Targamadzè, Girdzijauskienè, Šimelionienè, Pečiuliauskienè ir Nauckūnaitè, 2015, p. 98, cit. iš Leu et al., 2011). Kitas pastebètas tobulintinas aspektas - e. mokymosi kokybė, apimanti visus mokymosi ir švietimo procesus, rezultatus ir paslaugas, teikiamus pasitelkus informacines ir komunikacines technologijas (Pawlowski, 2007, 2008). Bendrąsias rekomendacijas švietimo kokybei gerinti ir sunkumams įveikti, pasitelkus mokslininkų išvadas, galima būtų suformuluoti taip:

- įvertinti studentų poreikius ir rezultatus;

- susigrąžinti prarastus mokymosi gebejjimus;

- sukurti efektyvią komunikacijos sistemą;

- stiprinti išplèstą mokymosi ekosistemą;

- palaikyti ir skatinti mokytojų profesinį tobulèjimą;

- sukurti veiksmingą nuotolinio mokymo(si) sistemą;

- ugdyti mišriojo mokymosi gebejjimus (Reimers, Schleicher, 2020).

Mišrusis mokymas yra lankstus modelis, tačiau naudingas tik tada, kai neįmanoma lankyti mokymo ịstaigos, ir labiau tinkamas kaip mokymo(si) metodas. Gerai organizuotas mišrusis mokymas(is) gali turèti daug privalumų: individualizuotų mokymą(si), padidintų besimokančiujų savarankiškumą, motyvaciją, tačiau silpnintų besimokančiujų socialinius iggūdžius ir bendruomeniškumo jausmą. Čia svarbiausia, kad sprendimai būtų paremti tuo, kas geriausia besimokančiajam, veiksmai kruopščiai suplanuoti ir sukurtas grižtamasis ryšys. Tačiau veiksmingesnis būdas - derinti tiesioginị mokymą(si) ir taikyti lankstų nuotolinị mokymą(si) tiek mokant(is) užsienio kalbų, tiek kitų studijų programų dalykų.

\section{Literatūra}

Börge Boeckmann K., Aalto, E., Abel, A., Atanasoska, T. ir Lamb T. (2011). Mehrsprachigkeit fördern Die Mehrheitssprache im vielsprachigen Umfeld. Graz: Council of Europe Publishing.

Hufeisen, B., Neuner, G. (2005). Mehrsprachigkeitskonzept - Tertiärsprachenlernen - Deutsch nach Englisch. Kapfenberg: Bachernegg.

Kazragyte, V., Gudaite, L. (sudaryt.). (2020). Ugdymo procesas, mokant nuotoliniu būdu: ǐ̌šūkiai, patirtys, sprendimai. Vilnius: Nacionalinè švietimo agentūra.

Melnikovas, A. (2017). Nuotolinio mokymo funkcijų genezè technologinio ir edukacinio virsmo paradigmų kontekstuose. Tiltai, 1, 113-126.

Pawlowsi, J. M. (2008). Globalaus mokymosi kokybè. Aukštojo mokslo kokybe, 5, 12-31.

Reimers, F. M., Schleicher, A. (2020). A framework to guide an education response to the COVID-19 Pandemic of 2020. Paris: OECD.

Targamadzè, V., Girdzijauskienė, S., Šimelionienė, A., Pečiuliauskienė, P., Nauckūnaite, Z. (2015). Naujoji (Z) karta: ar prarastoji, ar dar neatrastoji? Vilnius: Specialiosios pedagogikos ir psichologijos centras. 
Blended Learning in school education - guidelines for the start of the academic year 2020/21. (2020). Prieiga per internetą: https://www.schooleducationgateway.eu/downloads/Blended\%20learning\%20in\%20school\%20education_European\%20Commission_June\%202020.pdf

Europos Tarybos rekomendacija. (2018). Dèl bendruju mokymosi visa gyvenima gebejimu. Prieiga per internetą: https://eur-lex.europa.eu/legal-content/LT/ TXT/PDF/?uri=CELEX:32018H0604(01)\& from $=\mathrm{GA}$

Europos Sajungos C 189 oficialusis leidinys. (2019). Rezoliucijos, rekomendacijos ir nuomonés. Prieiga per internetą: https://eur-lex.europa.eu/legal-content/ LT/TXT/PDF/?uri=OJ:C:2019:189:FULL\&from=LT

Lietuvos Respublikos švietimo, mokslo ir sporto ministro $2020 \mathrm{~m}$. birželio 19 d. ịsakymas Nr. V-936 Dèl aukštuju mokyklu dèstytoju kompetenciju tobulinimo gairiu patvirtinimo. Prieiga per internetą: https: https://www.e-tar.lt/portal/lt/lega 1Act/9b11a070b22111eab9d9cd0c85e0b745?fbclid=IwAR1LDiNwMPo7Dr10KbF frzcqZFA2cwn7CHuMMnWmfTkk5Tp_S5dJ4AKkb2E

Nacionalinè švietimo agentūra. (2020). Nuotolinio mokymo(si) / ugdymo(si) vadovas. Prieiga per internetą: https://www.emokykla.lt/upload/nuotolinis/Nuotolinio\%20mokymo\%20Vadovas_3.pdf

Švietimo naujienos. (2020). Nuotolinis mokymas ar mokymo organizavimas nuotoliniu būdu? Prieiga per internetą: https://www.svietimonaujienos.lt/_trashed/

Švietimo problemos analizè. (2012). Nuotolinis mokymasis: mokymosi galimybiu išplètimas. Prieiga per internetą: https://www.smm.lt/uploads/documents/ kiti/Nuotolinis_mokymas.pdf

Švietimo problemos analizè. (2020). Nuotolinis mokymas ar mokymo organizavimas nuotoliniu būdu. Prieiga per internetą: https://www.nsa.smm.lt/ wp-content/uploads/2020/12/Nuotolinis-mokymas.pdf

Švietimo problemos analizè. (2012). Valstybinè švietimo strategija 20132022 m.: tikslai, problemos, tobulinimo kryptys. Prieiga per internetą: http://www. nmva.smm.lt/wp-content/uploads/2012/12/svietimo-strategija.pdf

Švietimo problemos analizè. (2012). Švietimo ịstaigu vadovai: ǐšsūkiai ir pokyčiai. Prieiga per internetą: https://www.nsa.smm.lt/wp-content/uploads/2021/04/ SPA-Nr.1-Svietimo-istaigu-vadovai_elektroninis.pdf 


\title{
CHALLENGES AND OPPORTUNITIES OF DISTANCE EDUCATION OF FOREIGN LANGUAGES AND IMPROVING DIGITAL COMPETENCE
}

\author{
Ingrida Galkauskienė, Jūratė Helsvig, Aušra Netikšienė, \\ Jūratė Patackaitè, Violeta Žemaitienè \\ Foreign Languages Centre of Vilniaus kolegija / University of Applied Sciences
}

\begin{abstract}
The article provides an overview of the documents prepared by the Ministry of Education, Science and Sports, regulating distance education, analyzes the aspects to be improved and new possibilities, which are based on the opinion of Lithuanian and foreign education experts, teachers from Vilniaus kolegija / University of Applied Sciences (hereinafter VK / UAS) Foreign Languages Centre and students who were studying foreign languages in 2020-2021.

The aim of the article is to provide the approach of lecturers and students to the distance education of foreign languages and after assessing the results of the research and recommendations of educational experts, to present the conclusions on how to adapt the experience to the development of distance foreign languages teaching tools, to organize practical activities and to ensure the quality of teaching foreign languages at a distance or blended level. However, according to the results of the study, it is necessary to admit that only $20.5 \%$ of VK / UAS teachers and students would choose distance foreign languages education, a relatively new way of teaching. The rest of the respondents would prefer to study foreign languages in a traditional way, communicating directly, without "mediators": "MS Teams" or VLE "Moodle" platforms. Nevertheless, the distance way of foreign languages education revealed certain advantages which influenced the choice of both students and lecturers' blended learning mode, i.e., by combining distance and contact teaching/learning. This is a definite merit of teachers' responsible work and good attitude towards students.
\end{abstract}

Keywords - teaching/learning of foreign languages, general competences, distance education, synchronous and asynchronous distance education, mixed teaching, quality of education 


\section{AUTORIŲ LYDRAŠTIS}

Autoriaus vardas, pavardė: Ingrida Galkauskienè

Darbo vieta ir pareigos: Vilniaus kolegija, Užsienio kalbų centro lektorè

Autoriaus mokslinių interesų sritys: lietuvių kalbos dèstymas užsieniečiams, nuotolinis mokymas, interaktyvūs mokymo metodai

Telefonas ir el. pašto adresas: +370 61240 308, i.galkauskiene@ekf.viko.lt

Autoriaus vardas, pavardė: Jūratè Helsvig

Darbo vieta ir pareigos: Vilniaus kolegija, Užsienio kalbų centro lektorè

Autoriaus mokslinių interesų sritys: profesinès anglų kalbos mokymas(is), besimokančiojo savarankiškumas

Telefonas ir el. pašto adresas: +370 61488 938, j.helsvig@eif.viko.lt

Autoriaus vardas, pavardè: Aušra Netikšienè

Darbo vieta ir pareigos: Vilniaus kolegija, Užsienio kalbų centro lektorė

Autoriaus mokslinių interesų sritys: profesinès anglų kalbos mokymas, IKT kalbų mokyme, projektinis mokymas, XXI amžiaus gebejjimų ugdymas

Telefonas ir el. pašto adresas: +370 68951 951, a.netiksiene@eif.viko.lt

Autoriaus vardas, pavardė: Jūratė Patackaitė

Darbo vieta ir pareigos: Vilniaus kolegija, Užsienio kalbų centro lektorè, Užsienio kalbų centro vedèja

Autoriaus mokslinių interesų sritys: pedagogika, užsienio kalbų mokymo metodai, daugiakalbystè

Telefonas ir el.pašto adresas: +370 61577 203, j.patackaite@vvf.viko.lt

Autoriaus vardas, pavardė: Violeta Žemaitienė

Darbo vieta ir pareigos: Vilniaus kolegija, Užsienio kalbų centro lektore

Autoriaus mokslinių interesų sritys: kūrybiniai ir interaktyvūs mokymo(si) metodai, profesinè vokiečių kalba, nuotolinis mokymas(is)

Telefonas ir el. pašto adresas: +370 69907 259, v.zemaitiene@vvf.viko.lt 


\section{AUTHORS' COVER LETTER}

Author's name and surname: Ingrida Galkauskienè

Workplace and position: Lecturer of Foreign Languages Centre, VK / UAS

Author's research interests: Lithuanian language teaching for foreigners, distance learning, interactive methods

Telephone and e-mail address: +370 61240308, i.galkauskiene@ekf.viko.lt

Author's name and surname: Jūratė Helsvig

Workplace and position: Lecturer of Foreign Languages Centre, VK / UAS

Author's research interests: ESP teaching, learner autonomy

Telephone and e-mail address: +370 61488 938, j.helsvig@eif.viko.lt

Author's name and surname: Aušra Netikšienè

Workplace and position: Lecturer of Foreign Languages Centre, VK / UAS

Author's research interests: ESP teaching, ICT in language teaching, project-based teaching, developing 21 st century skills

Telephone and e-mail address: +370 68951 951, a.netiksiene@eif.viko.lt

Author's name and surname: Jūratė Patackaitė

Workplace and position: Lecturer, Head of Foreign Languages Centre, VK / UAS

Author's research interests: pedagogy, foreign language teaching methods, multilingualism

Telephone and e-mail address: +37061577 203, j.patackaite@vvf.viko.lt

Author's name and surname: Violeta Žemaitienè

Workplace and position: Lecturer of Foreign Languages Centre, VK/UAS

Author's research interests: creative and interactive teaching/learning methods, professional German language, distance learning

Telephone and e-mail address: +370 69907 259, v.zemaitiene@vvf.viko.lt 